\title{
AUTOFICÇÕES DE MÁRIO
}

\author{
Eneida Maria de Souza \\ UFMG
}

Quando o movimento literário e artístico que abalou os primeiros anos do século completa 70 anos, a primeira reação é a de reverência a um tempo inegavelmente marcado por grandes mudanças culturais no país. Por outro lado, quanto mais velho o movimento, maiores oportunidades se apresentam para sua avaliação, pois estamos todos aparentemente mais maduros e literalmente "fin-de-siècle".

Com os olhos no presente e a atenção voltada para a releitura do passado, é que pretendo refletir sobre o movimento modernista brasileiro, escolhendo um de seus maiores expoentes Mário de Andrade - e analisar, através de sua correspondência com os mineiros, a constituição de seu auto-retrato como escritor, pesquisador e homem público. A eleição de Mário como representativo desse momento cultural permite que se compartilhe do seu ideal de repensar o Brasil, retrato que estava sendo também esboçado e re- 
tocado pelos demais componentes da banda modernista. Retomar, nos tempos atuais, essa empreitada construtivista consiste igualmente num projeto inacabado que exige sempre a agudeza de uma diferente visão.

O exame da correspondência de Mário de Andrade tem o mérito de promover a elucidação de seus textos ficcionais, além de fornecer subsidios para se delinear o perfil do intelectual modernista. A importância revelada pelo documento autobiográfico não incide apenas nos aspectos anedóticos da biografia do autor, mas na oportunidade de se refletir sobre a relação entre arte e vida, produção epistolar e ficcional, projeto estético e projeto político. ${ }^{1}$

A abertura para diferentes perspectivas analíticas na obra do autor de Macunaíma deve-se à crescente publicação de textos inéditos e de sua produção marginal, tais como os comentários, notas escritas ao lado da obra e os inúmeros documentos que ainda exigem cuidada leitura. As cartas, por sua vez, ao serem consideradas variação do relato autobiográfico, exercem igualmente a função de reacender o lado apagado da criação e de realçar os esboços e rascunhos de uma provável "obra-prima" ainda não reconhecida. Pesquisas recentes, voltadas para a decifração do "grande texto" marioandradino, notadamente aquelas nascidas no Instituto de Estudos Brasileiros da USP, reforçam a intenção de inserir a produção intelectual do autor no projeto mais amplo de construção da moderna cultura brasileira.

Nesse cenário textual, marcado pela dramatização do enunciado, insere-se o sujeito, configurado nas imagens do autor, do artista, do intelectual e do homem público, papéis representados pelo escritor modernista. $\mathrm{O}$ desdobramento das múltiplas feições assumidas pelo sujeito, no interior da ideologia que compõe o quadro intelectual da época, constitui, na realidade, o foco

1. Essa posição já se acha esboçada em dois de meus artigos, publicados respectivamente em 1990 e 1991, intitulados "Relíquias da casa" e "Mário retorna a Minas". central deste ensaio.

A escolha do corpus para estudo restringe-se à correspondência, publicada em livro, de Mário de Andrade com os mineiros, durante o período que vai de 1940 a 1945 . Desse material foram selecionadas as cartas de Mário a Drummond, $A$ lição do amigo (1982), a Henriqueta Lisboa, Querida Henriqueta (1990), e a Rodrigo Mello Franco de Andrade, Cartas de trabalho (1981), que funcionarão como base de articulação de temas comuns entre os textos e entre a correspondência mantida com os escritores.

Essa produção epistolar é composta de vários destinatários pertencentes a diferentes gerações. Inicia-se com a vinda da caravana paulista a Minas, em 1924, da qual Mário é um dos integrantes. São as cartas endereçadas a Drummond, Nava e Emílio Moura, primeiros destinatários do arauto da vanguarda paulista e figuras de destaque do então nascente modernismo mineiro. Em 1939, revisitando Minas, Mário conhece novos escritores que irão igualmente compartilhar do privilégio de se receber carta da rua Lopes Chaves: Murilo Rubião, Henriqueta Lisboa, Fernando Sabino, Paulo Mendes Campos, Helio Pellegrino, Alphonsus Guimarães Filho, Francisco Iglésias, João Etienne Filho e outros. As cartas trocadas com Rodrigo Mello Franco de Andrade, diretor do Patrimônio Histórico e Artístico Nacional, têm início em 1936, época em que Mário de Andrade trabalha no Departamento de Cultura do Município de São Paulo.

Inúmeros são os motivos que me fizeram escolher o período de 1940 a 1945 para a análise da correspondência desse escritor. Entre os mais relevantes, destacam-se os seguintes: a) necessidade de limitar o corpus de trabalho para melhor operacionamento temático e conceitual, imposição de ordem metodológica; b) interesse em refletir sobre os últimos anos do escritor, repartido entre cargos públicos e sua atividade intelectual, empenhado na preservação do acervo cultural do país e preocupado com o momento por que passava a literatura, marcado por graves problemas politicos; c) relevância, nos textos desse 
período, da urgência em realizar o balanço do projeto estético e político do modernismo, a par de evidentes contradições assumidas pelo intelectual, dividido entre um projeto coletivo de cultura e o individualismo artístico.

A leitura recente das cartas de Mário a Henriqueta forneceu o tema e o ponto de partida deste ensaio, não só pelo fato de o texto se circunscrever ao período final da vida do escritor, como pelo tom confessional e retrospetivo conferido à escrita. Neste esboço de biografia intelectual de Mário, emprego a metáfora pictural do auto-retrato sugerida pelo teor da carta endereçada a Henriqueta Lisboa, em 11 de julho de 1941. Nesta, a imagem do autor de Macunaíma é revisitada pela mediação dos retratos feitos pelos amigos, artifício retórico utilizado para falar de si. A metáfora traduz a maneira pela qual a imagem se compõe - fragmentariamente e pelo olhar do outro - e o meio escolhido para expressá-la: o exercício cotidiano do gênero epistolar. Por sua vez, o conceito de auto-retrato, pertencente ao domínio das artes plásticas, ao ser transposto para o texto ensaístico, descolase de seu sentido próprio e se integra na rede associativa de imagens discursivas.

$\mathrm{O}$ auto-retrato andradino recebe pinceladas de seu autor e dos outros que partilham dessa criação, devolvendo-lhe imagens verossimeis ou deformadas, conforme o traço particular de cada observador. $\mathrm{O}$ auto-retrato se desdobra na produção literária, ensaística e documental, bem como nos vários acontecimentos da vida pública protagonizados pelo escritor. Em virtude da extrema variedade de elementos que concorrem para a composição heteróclita do retrato de Mário, elegi essa metáfora como foco que se projeta em abismo no texto da vida e da obra.

Utilizando-me de um procedimento próprio à montagem e à colagem modernas, construo o retrato de Mário em fragmentos, acentuando os detalhes e pequenos traços que se superpõem no quadro. Em vista do apagamento de elementos que constituem a assinatura desse retrato, escolhem-se lugares, textos, posições políticas, ges- tos e frases do escritor, fragmentos de seu texto escrito e vivido, conferindo-lhes o estatuto de objetos e de lugares teóricos. A atuação do escritor na vida política e a realização de estudos, projetos e criação literária compõem o retrato do último Mário. Os textos escolhidos para análise serão articulados entre si a partir da utilização do auto-retrato como metáfora condutora $\mathrm{e}$ do processo de colagem que superpõe imagens discordantes.

A presença dos destinatários mineiros como interlocutores do diálogo com Mário de Andrade contribuirá para recompor, de forma diversificada, os traços de um retrato intelectual eivado de contradições. $O$ relacionamento entre eles se pauta tanto pela amizade desinteressada e pelo pacto amoroso estabelecido, quanto por uma ligação comprometida por interesses pessoais e políticos. Não cabe, no momento, traçar o perfil dos interlocutores, mas considerá-los como testemunhas silenciosas - não se tem ainda acesso às suas cartas - de um projeto ambicioso e polêmico de construção da identidade nacional, num período marcado por grande descompasso ideológico.

É inegável a afirmativa de ser o leitor peça fundamental do gênero epistolar, compondo com o emissor um diálogo em diferença com relação aos outros. A comparação entre as cartas examinadas permite verificar até que ponto assuntos semelhantes são tratados de forma diferente mais intensos em uns, velados ou, às vezes, esquecidos em outros. As anotações dos autores ou organizadores dos volumes de correspondência constituem ainda rico material para se pesquisar sobre o recorte diferenciador realizado pelo leitor.

\section{EU É QUE ESTAVA ME PINTANDO...}

$O$ conceito de auto-retrato, transposto para o texto escrito, irá se distinguir da autobiografia pela carência de um relato cronológico de experiências, que se iniciaria, fatalmente, pelo nascimento, seguido de acontecimentos logicamente encadeados. No entender de Beaujour, no seu 
livro Miroirs d'encre, o auto-retrato vale-se de uma técnica que se aproxima do relato metafórico e poético, graças ao processo de montagem, construído de reprises, superposições e correspondências entre os elementos homólogos. Postula a existência de um gênero que se filia ao ensaio, por apresentar-se como texto anfíbio e inclinar-se tanto para a fícção quanto para o documento. Situando-se ainda no limite entre ficção e teoria, o auto-retrato pertenceria à categoria dos discursos próprios aos Ensaios de Montaigne, ao Ecce Homo, de Nietzsche ou ao Roland Barthes por Roland Barthes. ${ }^{2}$

Texto que reflete a si próprio, se auto-analisa e tem como referente a imagem do sujeito, é inerente ao auto-retrato a prática do comentário, a revisão constante e obsessiva de seu próprio fazer. (Comentar a própria vida e conferir nota às obrigações e tarefas diárias são práticas do "cuidado de si" reveladas por Mário de Andrade em diversos momentos de sua correspondência). A colagem de elementos superpostos da biografia supõe a fragmentação do sujeito na linguagem e a construção de um texto que foge aos parâmetros do relato tradicional da experiência. Moderno por excelência, o sujeito do auto-retrato se esboça enquanto ficção e dramatiza sua dimensão empírica, dimensão que muito tem ainda moldado os estudos de ordem biográfica. Associado ainda à técnica do esboço, o auto-retrato promove maior aproximação entre vida e arte, pela natureza inacabada e precária de ambas as instâncias simbólicas. Escrita de mão dupla, na qual se cruza a via da ficção com a da realidade.

O processo de construção do auto-retrato relaciona-se também ao que Barthes denomina de biografemas, ou seja, a valorização que se deve conceder, numa biografia, aos detalhes, a "alguns gestos" e inflexões, manifestações alheias a todo e qualquer desejo de totalização. $O$ biografema zomba da estrutura fechada da biografia, procedendo, obliquamente, na leitura de fragmentos, restos e sobras dos sujeitos. ${ }^{3}$

2. BEAUJOUR. 1980.

3. BARTHES, 1971. p.14.
Mário de Andrade, ao reler trechos de sua carta publicados em artigo de Drummond, reconhecese dominado pelo esquecimento, expresso na carta, pelas reticências e parênteses do não-dito - posição que antecipa a futura concepção barthesiana de biografema:

Pois, Carlos, que coisa estupenda! quando eu li os trechos de cartas minhas que você citava, era maravilhoso: eu me lembrava! Eu me lembrava, sim, seu Carlos, e de que maneira! não era só lembrar as idéias, os raciocínios, essas coisas mais ou menos lógicas era natural que eu me lembrasse. Eu me lembrava era de ilogismos, de exclamações, de idéias laterais, de parênteses. Eu me lembrava mais: lembrava dos momentos em que escrevera aquilo, as sensações se repetiam quase integrais nos trechos mais longos, hora, estado físico, momentos circundantes do que eu escrevera aquilo! Está claro que isso é o que mais me absolve das minhas cartas. Foram escritas com tamanho amor, tamanha integração, tão decisórias como esses momentos raros de que a gente nunca se esquece na vida. ${ }^{4}$

A falta de memória constitui, em Mário, um dos principais dados referentes à constituição de seu auto-retrato; a lembrança do outro atua como estímulo à memória do eu, que se vê sempre em migalhas. Os acontecimentos lembrados têm, para ele, a sutileza e o abandono de uma imagem de salão depois do baile: "pelos riscos no chão, pelas migalhas, pela desordem das cadeiras, a gente percebe que muita coisa se passou ali..."

A posição teórica de Beaujour quanto ao autoretrato apresenta alguns pontos polêmicos. Entre eles, gostaria de destacar a defesa do caráter

\footnotetext{
4. ANDRADE, 1982, p.215-6.

As indicações desse livro serão, daqui para frente, feitas no corpo do trabalho, utilizando-se a sigla LA; as outras indicações referentes às Cartas de trabalho e à Querida Henriqueta receberão a sigla $\mathrm{CT}$ e $\mathrm{QH}$.
} 
atemporal e ahistórico desse tipo de texto. Pelo fato de se ter uma interpretação textual e psicanalítica do auto-retrato, concentrando-se na sua dimensão enunciativa, Beaujour privilegia o estatuto imaginário do sujeito no discurso. A preferência deve-se à oposição entre auto-retrato $\mathrm{e}$ autobiografia, calcada na diferente posição que cada gênero assume diante da história e do tempo. No seu entender, o lugar histórico do sujeito que escreve seu auto-retrato desaparece em favor de uma atemporalidade mítica e imaginária.

A pouca importância conferida ao aspecto diferencial que caracterizaria 0 auto-retrato de Barthes em relação ao de Montaigne deve-se à ênfase nos aspectos estruturais e internos dos textos. Historicizar o auto-retrato sem cair na redução historicista tem o objetivo de analisar as cartas de Mário de Andrade como expressão do auto-retrato do sujeito moderno, inserido numa época especifica de sua vida. Os vôos e deslizes praticados na elaboração de uma visão histórica desprovida de maniqueísmos, reduções e empirias, traduzem minha proposta analítica.

As cartas de Mário de Andrade aos mineiros serão analisadas como se formassem um conjunto de fragmentos textuais, reunidos conforme o recorte temático aí realizado - acontecimentos, pedaços de frases, imagens e retratos do autor desenhados por ele ou por outros. O recorte temático possibilita ainda o jogo ambivalente de passado e presente, o embaralhar das datas e a aproximação de elementos díspares, construindo-se a montagem textual que permanece, contudo, com um pé na "verdade" ficcional e o outro na "ficção" histórica.

Entendidas enquanto corpo fragmentado que vai sendo repartido com os variados leitores, as cartas representam ainda a imagem das migalhas do eu que se manifesta de forma esquiva ou confidencial, conforme o grau de receptividade do leitor. Necessidade de participar com o outro, de atuar no outro e de ter a parcela de responsabilidade na construção do texto alheio. Escrita interminável, cujo ponto final, dado pela morte do escritor, continua, no entanto, sendo reescrito infinitamente.

\section{ESTOU DE NOVO BOM E MACIO}

Enfim estou reprincipiando a minha vida. Ainda tive de voltar ao Rio, desfazer apartamento, ver se ajeitava meu caso de funcionário e uma questão de pagamentos em atraso me prendeu lá por quase um mês. Agora estou arrumando minhas coisas pra recomeçar no trabalho e espero que naquele mesmo ritmo mais regular de vida que sempre tive aqui (...). A minha casa me defende, que sou, por mim, muito desprovido de defezas. E sobretudo a minha casa me moraliza, no mais vasto sentido desta palavra. Até quando a me tornar mais normalmente produtivo naquilo que eu sou. (...) Estou bom, Henriqueta, estou de novo bom e macio. Faz Carnaval lá fora num ar chuvoso, quase frio. Agora vou jantar. Depois me visto sossegado, vou dar uma volta pelo carnaval mole e bêsta dos paulistas, sem convite nenhum. não verei nada, com o pensamento em mim. $^{5}$

A volta de Mário de Andrade a São Paulo, em 1941, é o assunto desta carta a Henriqueta Lisboa. Nela, o escritor se depara com a imagem de quem se vê, de novo, instalado na sua casa da rua Lopes Chaves, após a estada de três anos no Rio. Entre amargurado e satisfeito com o retorno à casa, o escritor valoriza a segurança reconquistada, trazida pelo conforto burguês de ter as coisas nos seus devidos lugares. A casa defende e moraliza, devolvendo-lhe, simbolicamente, a integridade perdida durante os anos passados no Rio, época conflituosa que serviu, contudo, de refúgio para as decepções políticas sofridas enquanto diretor do Departamento de Cultura do Município de São Paulo. Retornar à casa moraliza, por restituir ao escritor a produtividade no trabalho, reativando sua natureza disciplinada

5. ANDRADE., 1990, p. 43 - 4. 
e metódica; defende, por se sentir protegido no meio da família, da mãe que lhe passa as roupas e lhe prega os botões, bambeados. Cercado de sua coleção de objetos de arte, quadros, livros e desenhos, Mário de Andrade confessa ser o seu cantinho o "retrato alindado" de si.

Em sua última carta a Drummond, de 11 de fevereiro de 1945, Mário compõe simultaneamente o retrato dos amigos ao lado do seu, ao apontar para a diferença de uma visita a sua casa, por Henriqueta e pelo poeta mineiro. À poetisa é dada a intimidade da sala de jantar, do convite para o almoço, enfim, o acesso ao espaço doméstico comportado e bom. Ao amigo, a liberdade do espaço da rua, da conversa de homem para homem, da integração entre dois poetas que se entendem e se respeitam mutuamente. Mas a evocação do espaço público muda agora de alvo: antes, o compromisso sério do trabalho, hoje, a farra nas "boîtes francesas", nos "mosqueiros italianos"

Tantas, tantas coisas. Estou esperando neste momento a Henriqueta Lisboa que vem almoçar aqui em casa. Quando você viria?... Aliás, penso que você eu não convidava para almoçar aqui em casa, como nunca convidei o Manuel. Prefiro mostrar os milagres de São Paulo, as boîtes francesas, os mosqueiros italianos. Mas a Henriqueta é tão tênue, tem tamanhas restrições na comida que prefiro assim. Você eu queria que primeiro dissesse bom dia a mamãe, e depois vínhamos pra esta sala de trabalho, gosto dela, sabe, é o meu retrato alindado, como os dos fotógrafos, parece comigo mas é cem vezes mais bonita. Mas não é feita para inglês ver, se vive nela, e ficávamos assim no largado que-fazer da intimidade. 6

A intimidade da casa, aberta a Drummond, tem a cumplicidade do olhar distanciado da mãe e se restringe à sala de trabalho, assim como o teor

6. ANDRADE, 1982. P. 242 - 3. das cartas endereçadas ao amigo se distingue daquele verificado nas cartas a Henriqueta. A relação mais afetuosa e familiar que une Mário à poetisa difere do elo de ligação mais "viril" e intelectual que une os dois poetas. Afastada do grupo masculino de escritores - por ocasião do "Congresso de Escritores", em São Paulo, Mário escreve a Henriqueta e expressa o sentimento de que seria, realmente, bom ela não ir, pois não teria tempo para se dedicar a todos -, a poetisa é, portanto, a presença feminina que funciona, para Mário, como o espelho do seu lado bom e humano: "...você é uma asa que me voa para Deus. Tudo de você me cristaliza no Bem, a sua humanidade, o seu esquecimento, os seus poemas, as suas cartas, e agora este meu poema e esta antologia dos místicos espanhóis. ${ }^{17}$

O lugar diferente ocupado na casa do escritor pelos dois amigos se compara ainda à distinta poética apresentada por Henriqueta e Drummond. Pautada por um tom mais reflexivo e "fatalizado", a poesia de Henriqueta se concentra numa expressão universalista e descontextualizada. $\mathrm{O}$ conselho de Mário à amiga para que não perca seu traço próprio e sua "fatalidade" responde à intenção de Henriqueta de fazer poesia de combate. Essa proposta, presente na poesia de Drummond, não representa, para Mário, a única forma de valorizar a literatura e nem um critério válido para toda poesia. Por reconhecer a diferença entre a produção artística da poetisa e a de seus contemporâneos, Mário agudamente assinala o lugar ocupado por Henriqueta Lisboa na Literatura Brasileira: "Continue fazendo a sua poesia fatalizada, que ela é tão social como qualquer poema de Neruda ou de Carlos. Não imagino, não sinto, nem quero, você fazendo poesia de combate. Não é de seu temperamento, nem de sua personalidade. não que eu queira reduzir você a uma feminilidade antiga de recato estigmatizado e feitura de bolos e crochês."

O ambiente é, ainda, um retrato mais "alindado" e caprichado do escritor, além de funcionar si-

7. ANDRADE, 1990, p. 136.

8. Ibidem, p. 156. 
multaneamente como espaço ambivalente que se liga à sua imagem: sala de trabalho e sala de visita, espaço íntimo e público, casa familiar e museu, lugar em que seu proprietário se recolhe $\mathrm{e}$ se expõe. Considerar a sala de trabalho como o retrato mais "alindado" de si relaciona-se, por outro lado, com um dos princípios da poética modernista, voltado para a estetização do cotidiano: a poesia que se extrai do dia-a-dia, dos acontecimentos de menor importância ou dos objetos que compõem o imaginário estético do poeta. Em carta a Henriqueta, ao discorrer sobre a transformação do "pessoal no humano", Mário afirma que essa transfiguração não se processa pelo tratamento retórico e eloqüente dos grandes temas. Ao contrário, ela está presente na realização poética de Drummond e de Bandeira - o primeiro, ao "fazer de uma topada, a pedra no caminho", o segundo, de uma "janela de nenhuma vista", fazer "O Beco".

O sentimento de moralidade sugerido pela casa se oporia às "saudades imoralizadoras" do tempo vivido no Rio, cidade que acentua sua imagem hedonística - o homem "fraco, sensual e imoral" que é. O aspecto imoral de seu retrato é o resultado da entrega inconseqüente às solicitações da rua ou, num sentido mais amplo, ao prazer encontrado na vida pública, onde o controle das ações torna-se mais difícil do que em ambiente privado. $\mathrm{O}$ sujeito se expõe, se dá em espetáculo, resultando fatalmente na má interpretação de seu papel pelo outro.

O escritor culpa ainda a cidade do Rio pelos "defeitos dos homens", por ser o clima tropical um convite à preguiça e à entrega às ações sensualmente irresponsáveis. Cidade onde o escritor "tem um emprego sem trabalhar", conflito profissional do servidor público morando no Rio. Inaceitável, ainda, como "cabeça de uma civilização", o Rio deveria, nas palavras de Mário, deixar de ser a capital do país. A razão para tal é estar o Brasil comandado pelos gaúchos, mineiros e paulistas, representantes de climas temperados e, conseqüentemente, mais inclinados ao trabalho e à produtividade. Macunaíma teria re- plicado, em alto e bom tom, que a "civilização européia é que esculhamba com a inteireza do nosso caráter".

Em trecho de carta a Drummond em 1936, antes de ir para o Rio, Mário se comporta macunaimicamente, disposto a enfrentar o clima quente e a ceder aos encantos do sonho carioca. O lado intuitivo e sensual de sua formação fala mais alto quando necessita "esquecer" São Paulo e mudar de clima político: "Confesso que o clima do Rio é o meu clima, nasci pra calor, ao passo que aqui agora mesmo faz quatro meses que estou sofrendo do ouvido por causa de um resfriado tremendíssimo. O Rio pra mim é um sonho e eu quàse que me envergonho de você ter me obrigado a confessar isso." ${ }^{\prime 9}$

O desabafo de Mário não pode ser interpretado isoladamente, mas como expressão de seu conflito permanente com a questão do lugar do intelectual, dividido entre o projeto estético e o político, a realização pessoal e o engajamento coletivo. Esse conflito irá pautar a trajetória intelectual do escritor, ciente das contradições a que está sujeito, manifestadas sempre pelo teor irônico, e muitas vezes apaixonado, de suas declarações.

A culpabilidade atribuída à cidade do Rio pelo "vício dos homens" reflete mais uma das saídas ambivalentes exercidas pelo pensamento de Mário quanto à problematização do nacionalismo e da identidade. Nessa época, o seu projeto estético caminhava para o engajamento social e político, fortalecido pela participação nos cargos públicos e pela elaboração de anteprojetos culturais, como o do SPHAN, que contemplavam, ao mesmo tempo, a ideologia política e cultural de modernização do país e a convivência da tradição com a vanguarda. Os princípios racionalistas e universalistas que norteiam essa proposta objetivavam a instauração de métodos científicos de análise da cultura, a exemplo do que acontecia nos países civilizados. Eliminar o excesso de intuição e ponderar sobre a necessidade de um

9. ANDRADE, 1982. P. 187. 
projeto coletivo que congregue as expressões individuais são os princípios que norteiam o texto marginal do escritor.

$O$ que na realidade se recalcava nessa postura naturalista e fatalizada de cultura era o descompasso do escritor com a sua participação política no governo Vargas, levado pelas mãos amigas de Capanema e Drummond. A consciência tumultuada pela convivência com os bastidores da política e as decepções daí advindas _- "o ser não-sendo, ter um emprêgo e não trabalhar, ter uma casa, família, livros, obras-de-arte e longe disso" - contribuíram fortemente para o desabafo com Henriqueta e o recolhimento do escritor na "verdade" de sua casa paulista.

Atitude semelhante havia sido experimentada, em carta de 1938 a Rodrigo Mello Franco, na qual o escritor, ao ser convidado para se transferir para o Rio após os embates sofridos no Departamento de Cultura, confessa ao amigo seu desinteresse em assumir um cargo público de grande repercussão, preferindo, modestamente, gozar do anonimato e da obscuridade. Silviano Santiago, em seu artigo _- "O intelectual modernista revisitado" 10 — dedicado à atuação de Mário enquanto diretor do Departamento de Cultura de São Paulo e futuro funcionário do Governo Federal, analisa acuradamente o conflito do escritor diante das artimanhas e dos descompassos políticos. Assinala ainda as decepções que o serviço público provoca no escritor e as inevitáveis contradições verificadas na sua atuação como homem público.

Para expressar seu desalento pela situação em que se encontrava, Mário emprega a mesma metáfora visual que mais tarde irá utilizar na carta a Henriqueta. Expressa o desejo de recolhimento interior do sujeito através da negação da visibilidade: - "não verei nada, com o pensamento em mim." Em 1938, a situação é de gravidade, exigindo-se, para tal, maior radicalidade no processo de apagamento de sua imagem. $O$ refúgio na escuridão e o apagar das luzes do palco são a

10. SANTIAGO, 1989. saida para o momento: "Prefiro mil vezes um posto que me conserve na obscuridade, subalterno de outros que mandem em mim e a quem obedeça sem responsabilidade. Quero escuridão, não quero me vingar de ninguém, quero escuridão (...). Agora prefiro é descansar e não ver, nem ser visível."11

A integridade reconquistada imaginariamente pela volta à casa traduz muito mais o desejo de recuperar simbolicamente a integridade paulista, pela conjunção do escritor com o espaço que sempre lutou por preservar. A inclinação em defender a integridade da casa paulista não assume as proporções verificadas na carta a Drummond, de 1932, por ocasião da Revolução Constitucionalista. Nesta, o sentimento de defesa de São Paulo chega às raias do exagero e o bairrismo suplanta o nacionalismo. Persiste, no entanto, na carta a Henriqueta, o eco de uma derrota e a retomada de uma reflexão sobre São Paulo: "Agora eu sou paulista. Não sinto o Brasil mais, e ainda não readiquiri a minha internacionalidade. Retrogradei vinte anos na minha vida. Voltei ao menino estudante que inda tinha senso político de pátria. E minha pátria é São Paulo. E isso não me desagrada! (...) Não sinto o imenso Brasil, não sinto a minha Paraíba, não sinto Minas, nem nada." 12

A cidade se fantasia de ar sério e chuvoso, cenário usual de um carnaval paulista. A atitude contida e retraida do sujeito se manifesta pela necessidade de fechar os olhos para o exterior. $O$ retrato da cidade - sem muita luz e sem alardes, "macio e bom" - é composto pelo olhar subjetivo de quem aí se espelha. Desprovida da sensualidade do "carnaval carioca" e reprimida pela disciplina a ela imposta, a cidade revela o "lado bom" da personalidade de Mário, bondade que se reveste do sentimento de amargura e do espírito acomodado diante dos fatos. É esta uma das poses assumidas pelo escritor na pintura de seu auto-retrato.

11. ANDRADE, Cartas de trabalho, p. 132.

12. Ibidem, p. 179. 


\section{ENTRE O ANJO E O DIABO}

A duplicidade do intelectual que se debate entre a vida privada e a vida pública, entre o projeto estético e o político se consubstancializa em vários pares de oposição que giram em torno do bem e do mal, da moralidade e da imoralidade, sem que haja uma correspondência exata entre os termos das equações. Múltiplas figurações surgem no conflito paradoxal entre essas categorias, relativas à moral cristão, e inúmeras vezes reiteradas pelo escritor na sua obra. A extrema versatilidade assumida pelos termos impede que a relação entre eles seja binariamente interpretada.

Os retratos do escritor, pintados respectivamente por Segall e Portinari completam, segundo Mário, a sua imagem, ao representarem, picturalmente, o seu lado bom e o seu lado mau. Servindo-se da mediação artística para recompor e remexer o seu retrato, o sujeito que aos poucos vai sendo reconstruído traz o crivo da ficção e o olhar do outro. Esse procedimento é significativo para se teorizar sobre o estatuto do auto-retrato, estendido como expressão da pose e do distanciamento do sujeito de sua própria imagem. Ao expor a subjetividade por intermédio da imagem que o outro compõe de si, o sujeito percebe que ele também concorre para a elaboração do seu retrato. Comporta-se, dessa forma, como o $e u$ que se afasta e se aproxima da própria imagem.

A justificativa fornecida pelo escritor para explicar a diferença entre um retrato que exprime o seu lado bom e, outro, o seu lado mau, se funda no princípio de doação, de charitas que preside a criação artística. Consiste, portanto, no grau de afinidade existente entre sujeito e objeto, o que irá provocar maior aproximação ou distanciamento.

Esse princípio irá pautar a análise do auto-retrato que Mário vai compondo de si, seja por intermédio da imagem do outro, seja pela configuração de seu retrato escrito.
O sentido de charitas, expresso por Mário em carta a Oneyda Alvarenga, consiste na identificação amorosa e religiosa vivenciada pelo sujeito, na tentativa de captar o que o objeto pode lhe oferecer. Considerada em termos mais abrangentes, a doação é, para o escritor, o entregar-se com paixão a tudo o que faz, tanto no que diz respeito ao gesto artístico quanto ao da experiência.

Na reelaboração de seu retrato, pela mediação do quadro feito por Portinari, Mário atualiza o princípio de charitas, ao reclamar para si o direito de autoria da imagem pintada pelo amigo. Pelo fato de ser a relação entre os dois marcada pela amizade, o retrato que Portinari cria é aquele que Mário ajudou a construir: o seu lado bom, a sua doação ao amigo. Segall, ao contrário, desenha o lado mau, pela inexistência de afinidades entre eles e pela ausência de um sentimento de troca. Como conseqüência, o lado mau de Mário salta na tela:

O retrato feito pelo Segall foi êle mesmo sozinho que fez. Não creio que o Segall, russo como é, judeusíssimo como é, seja capaz de ter amigos. Pelo menos no meu conceito de amizade, uma gratuidade de eleição, iluminada, sem siquer pedir correspondência. Éramos ótimos camaradas e apenas. Como bom russo complexo e bom judeu místico êle pegou o que havia de perverso em mim, de pervertido, de mau, de feiamente sensual. A parte do Diabo. Ao passo que o Portinari só conheceu a parte do Anjo. Às vezes chego a detestar, (me detestar) o quadro que o Segall fez. É subterraneamente certo, mas, sem vânglória, o do Portinari é mais certo, porquê é o eu que eu gosto, que sou permanentemente e que chora, ainda e sempre vivo, mesmo quando a parte do Diabo domina e age detestada por mim. Esse quadro do Segall não fui eu que fiz, juro. $(. . .)^{13}$ 
A imagem boa que Portinari cria de Mário é aquela que ele queria que o amigo tivesse, é aquela construída pelo olhar de ambos. Os favores e a amizade são retribuídos na forma de uma imagem idealizada de bondade, despida do simbolismo que marca o retrato de Segall. A doação do sujeito para o outro deixa, assim, sua assinatura, no momento em que inicia a construção de sua imagem para esse outro. (Comparese, também, a referência de Mário ao poema de Henriqueta dedicado a ele, em que a imagem do escritor também se "cristaliza no Bem").

O Diabo completa o Anjo, assim como a face recalcada da maldade vem à tona pelo conflito com a face boa. Negar a autoria do retrato criado por Segall se iguala à posição de Mário frente à cidade do Rio de Janeiro, culpada pelo "vício dos homens". O clima tropical "imoraliza" os homens, impede a realização de um trabalho produtivo, da mesma forma que o lado mau revela verdades que o escritor gostaria de esconder. A exposição desse retrato registra o caráter indomável do inconsciente, do impensado e daquilo que ultrapassa ao controle do sujeito. Tem parte com o Diabo e a autoria é do Outro: "Esse quadro do Segall não fui eu que fiz, juro." Curiosamente, é esse retrato levado para o Rio, quando Mário ali se instala. Talvez para compor o perfil do pervertido e do mau, dominado pelo apelo do Outro.

Portinari, ao contrário, realçou as tintas da semelhança e da pretensa identificação do sujeito consigo próprio. Purificou a maldade e idealizou a arte, no desejo de mostrar que os "homens são milhores do que são". Uma arte que diz sim e que reúne as funções de otimismo e confiança na humanidade ou como diria mais tarde Mário no estudo que fez sobre a obra de Portinari: "Até os afrescos do Ministério, o artista responde à nossa esperança duma vida sadia e feliz." ${ }^{\prime 14}$

O retrato bom de Mário ultrapassa o âmbito individual, o auto-retrato particularizado, envolvendo-se numa aspiração de ordem coletiva, o que, na época, pautava o projeto estético e político dos dois autores do retrato.

O conflito entre essas forças constitutivas do perfil do escritor é ainda acentuado em carta a Henriqueta Lisboa, de 1942, na qual aponta para a necessidade de, nos contos autobiográficos, revelar inicialmente os traços de perversidade da personagem, para finalmente perceber que o lado bom sempre permanecia. Nega, assim, a "ruindade", pela incongruência estrutural verificada na construção da personagem do auto-retrato. $\mathrm{O}$ avesso revela, inconscientemente, o lado direito.

Mas é nessa mesma carta que a situação se reverte e tem-se a clara teorização de que a arte seria o componente mais eficaz para se explicar a vida. A bondade e a maldade, consideradas do ponto de vista da falsidade e da simulação, não passam de artefatos criados pelo sujeito, não passam de ficção. Os artifícios ficcionais constroem a existência e as ações vitais se revestem do mesmo tecido da obra de arte. O escritor tratou, portanto, de inventar-se uma vida e de fabricar o seu próprio papel, com os riscos que toda ficção apresenta, qual seja, a de tornar-se também infiel ao modelo, rompendo semelhanças e trapaceando verdades.

Em vez: por família, por educação e também, não sei si hereditariamente, por instinto, por amor ao Bem, eu me falsifiquei. Desde o princípio. Sou nobre, sou enérgico, sou isto, sou aquilo. Mas sei que nada é conquistado. Nada é fruto de uma vitória completa. Nada é de dentro para fora. Tudo é apenas casca, casquinha, epiderme. Tudo é uma hipocrisia cruel. ${ }^{15}$

\section{O MEU ESPETÁCULO ME APAIXONA}

A ficcionalização dos princípios éticos e sua transfiguração ao longo da obra de Mário de Andrade permite que sejam analisadas algumas imagens escolhidas para a composição do perfil 
do intelectual modernista. Essas imagens referem-se ao que Beaujour denomina "retrato in $f i$ gura", representação na qual o sujeito se apropria dos atributos de uma personagem (divindade, santo, herói mítico ou histórico) ao qual ele é assimilado. Essa prática, de uso freqüente nos auto-retratos do Renascimento, leva ao extremo a "imitação de Cristo", no esforço para apresentar e dividir os sofrimentos da paixão. $O$ exercício meditativo cristão valeu-se e continua a se valer desse procedimento, cujo exemplo mais conhecido são os Exercícios de Loyola. Nietzsche, em Ecce Homo, também se apropria dessa "representação in figura" de Cristo, na construção de seu auto-retrato. ${ }^{16}$

Esse recurso não difere da construção do autoretrato como "hetero-retrato", pois o autor irá se colocar no lugar do outro, esvaziando-se, dessa forma, a individualidade e promovendo o apagamento de uma imagem plena. $O$ esvaziamento funciona como forma de doação que excede os limites individuais, como foi observado na transformação gradativa que o conceito de bondade sofreu na interpretação que Mário fez do retrato pintado por Portinari.

As imagens escolhidas sintetizam o caráter dramático dos últimos textos do escritor e dos depoimentos aos amigos, além de revelar o "lado espetáculo" de sua personalidade intelectual e pública. A dedicação de Mário à prática cotidiana da correspondência traduz, por seu lado, a obsessão pelo conhecimento do outro e o desejo de se conhecer. A diluição da subjetividade no meio de outros eus que a formam contribui para a criação de um topos imaginário de constituição do sujeito. Aquele que se propõe escrever seu auto-retrato se inspira, fatalmente, na ancestral pergunta edipiana: "quem sou eu?", embora a resposta continue a ser um enigma.

\section{EIS O HOMEM!}

E foi a declaração de guerra que produziu, pra encurtar e ocultar as sujidades íntimas,

16. BEAUJOUR, 1980, p. 40. produziu o 'Movimento Modernista', a 'Elegia de Abril', a 'Atualidade de Chopin' e enfim explodiu no 'Café' como criação, e na doença como carne. $E$ foi neste último momento de criação, de outubro a dezembro passado, talvez o momento mais dramaticamente feliz de toda a minha vida, que eu percebi. Como eu atingira uma elevada moralidade de mim! Como eu estava (como homem) grande! Como eu me purificava em Homo! ${ }^{17}$

É este um dos "retratos in figura" apresentados por Mário na sua correspondência, evocando a imagem de Cristo no momento do Ecce Homo, de sua retratação pública. A utilização da figura reforça a condensação entre arte e vida e atua como força de aprimoramento pessoal. Evocada em carta a Henriqueta Lisboa, a imagem agora atinge dimensão dramática e heróica. A criação do poema Café, iniciado em 1933 e terminado em 1942, constrói o cenário da representação vivida pelo escritor. Antecedem o poema experiência vivenciada pela conferência "O Movimento Modernista" e pelos artigos "Elegia de abril" e "Atualidade de Chopin".

O corpo sofre como o de Cristo, por "experiência na carne", formando com a obra um só corpo, um só corpus. Partindo em defesa da "moralidade artística" no lugar da "moralidade estética", o autor reitera sua adesão aos preceitos da ética cristã e aos princípios da poesia política. À noção individualista de felicidade, significativa para se entender o otimismo da poética de Mário dos anos 20, acrescente-se a experiência dramática da dor, que o "moraliza" e o torna "milhor". A purificação em Homo, gerada pela obra-de-arte, possibilita a figuração do poeta em "carne-viva", oferecida em espetáculo e presentificada na enunciação: "Eis os homem".

O gesto criativo não obedece mais a um impulso subjetivo, de "dentro para fora", mas torna-se imperativo da causa social e da celebração da vida. A obra supera o autor. E enaltece o homem.

17. ANDRADE, 1990 , p. 138 
100 ANOS DE MÁRIO

A auto-retratação como Ecce Homo é também dramaticamente assumida na conferência " $\mathrm{O}$ Movimento Modernista", proferida em 1942 no Itamarati. Desnecessário esclarecer até que ponto Mário irá se representar como "consciência limite" do movimento, nas palavras de Carlos Guilherme Mota, uma vez que o balanço incluía não só o modernismo como também o papel do intelectual Mário de Andrade. Lúcido e cruel consigo próprio, o escritor aponta os erros e equívocos do movimento e realiza a revisão dolorosa de si.

Seguindo o mesmo traço que caracteriza o "auto-retrato in figura" do escritor, caracterizado pelo tema da doação e do sacrifício, encontra-se a apropriação da cena do III ${ }^{\circ}$ ato do poema $\mathrm{Ca}$ fé, presente em carta de 1943 de Mário de Andrade a Fernando Sabino. (Cartas a um jovem escritor). A cena reproduz, num contexto de guerra, a chegada do chefe revolucionário, moribundo, trazido por dois jovens companheiros para morrer junto às mulheres. $\mathrm{O}$ soldado que fica para receber o aceno do chefe para continuar no seu destino de luta encarna, simbolicamente, a figura do novo que deverá dar prosseguimento à ação interrompida do chefe, morto heroicamente.

Tal cena, enxertada no interior da carta de Mário, simboliza o relacionamento pessoal entre os dois amigos e funciona como "auto-retrato in $f i$ gura" do escritor, que se sacrifica em favor da vida do outro. A figuração heróica da doação, ampliada para o contexto literário e deslocada do aspecto meramente plástico, transforma a mensagem da obra-de-arte em lição de vida. Diferentemente da cena de Ecce homo representada em carta a Henriqueta Lisboa, a dramatização do relacionamento pessoal, ao mesmo tempo que aproxima seus personagens, os afasta. $\mathrm{O}$ destinatário da carta, saindo da personagem do poema Café, transforma-se em texto produzido pela ficção do escritor. A idealização e o aprimoramento da relação pessoal são mediatizados pela força da obra-de-arte que comanda a vida e a ultrapassa. A arte, portanto, cumpriria a fun- ção moralizadora ao pintar os homens melhor do que são na realidade _ a "imagem boa" do retrato de Mário por Portinari se multiplica em outros retratos.

Inserindo a cena heróica no interior da carta ao amigo, o texto epistolar assume igualmente a mesma função moralizadora da arte, não só por transformar as pessoas em personagens de um drama já escrito, como para exemplificar o princípio de "moralidade artística" — a superação do interesse individual em favor do coletivo presente na condensação da ficção com o real.

E assim, Fernando, que eu digo, sem demagogia nem exagero, que eu hoje dava a vida por você. Si você dissesse o mesmo, eu ficava danado como o chefe revolucionário. Recusava o seu adeus inútil, dizendo: Besta! vá viver! Hoje o que eu desejo simplesmente, além, acima do que você promete em arte é saber você, moço, vivendo. Bem entendido: como o moço revolucionário que foi arriscar a vida de novo por alguma coisa maior que o indivíduo. Mesmo porque si não houvesse a coincidência, não seríamos amigos. ${ }^{18}$

Incorporada à enunciação do texto, a cena heróica de Café realça as possiveis coincidências entre ficção e realidade, proposta a que Mário tanto se empenhou em defender. Ao jovem escritor é oferecida a dose de sacrifício, através do refrão, repetido duas vezes e lembrando uma litania: "eu hoje dava a vida por você".

\section{EU SOU UM TORRE-DE-MARFIM}

A terceira imagem que compõe o "retrato in $f i$ gura" do escritor não é assumida por ele, nascendo da acusação alheia de ser seu papel junto aos jovens semelhante ao de Drácula, daquele que se nutre do sangue dos outros. Funcionando, a princípio, em oposição a Cristo - figura representativa do sacrifício cristão -- Drácula ajuda a compor dialeticamente a imagem do es-

18. ANDRADE, 1981. P. 76. 
critor -- o lado mau do retrato de Segall. No lugar de dar a vida pelos outros, é o que suga, é quem, de certa forma, recupera a sua vitalidade pela relação egoísta com o outro.

Com o objetivo de relacionar essa imagem com a proposta estética de Mário e sua atuação como intelectual, escolhi um acontecimento representativo da sua última apresentação pública, o " 1 o Congresso Brasileiro de Escritores", realizado em São Paulo, em janeiro de 1945. A última carta de Mário a Rodrigo Mello Franco será utilizada como texto de referência, por constituir um documento no qual o escritor apresenta sua impressão do Congresso, além de incluir outras declarações paralelas.

Ia pedir, mas afinal nem peço desculpa de não ter ido na Estação abraçar você, você compreende. Não iria por protocolo não: queria ir. Mas estava exausto com os fins finais do Congresso, que pela $1^{\mathrm{a}}$ vez nele, não me deixei levar, escolhi um grupinho, com risco de ser indelicado, mas pra ser mais eu e me expandir livremente. Eram os quatro vintanistas que mais me dão o mistério, o insolúvel, mais me inquietam, mais me acaparam, mais amo: o Fernando Sabino e o Hélio, o Paulo e o Oto, do grupo dele. É que eu queria ir mesmo na Estação, se deu que chegando a hora de ir, lembrei de ir e quis ir. (...) Mas a vida estava tão alta e agradável que o seu botafora virara protocolo só. (...) Os amigos do 'meu tempo' já me atenazam porque eu só 'estava com os mineiros', e parecia um 'avô no meio dos meninos'. E sempre as brincadeiras sempre desagradáveis do 'mestre', 'professor', discípulos... ${ }^{19}$

Ou, em carta a Henriqueta, ao se referir claramente à acusação de que se comportava como Drácula. "Quando não é o insulto infamante e cachorro, como aquele do João Cesar Borba, que não me conhece e não conheço, dizendo em

19. ANDRADE, Cartas de trabalho, p. 186. artigo em que não teve siquer a dignidade de me chamar pelo nome, que eu era um Drácula, e me alimentava e à minha glória, do sangue dos moços. ${ }^{\prime 20}$

A atração pelo novo e pelo mistério, representada pela figura dos jovens mineiros, rompe com os protocolos e deixa o amigo e diretor do SPHAN, Rodrigo Mello Franco, abandonado na Estação. Movido pela mesma paixão exteriorizada pela vida, o gesto de Mário de se unir aos moços simbolizaria a transformação dos principios estéticos do Modernismo em princípios vitais, ao se apropriar do novo e se "alimentar do sangue dos moços".

Se, em 1924, a vinda dos modernistas a Minas teve a função de trazer a novidade estética do movimento para o grupo mineiro, ela desempenhou ainda o papel de descobrir a tradição, representada pela arte barroca. $\mathrm{O}$ culto do exótico e do "primitivo", experimentado pelas correntes de vanguarda européias, encontra no barroco o solo propício para se instalar. Os modernistas não precisariam mais sair à cata de exotismo.

A situação do momento se inverte. Minas não representa mais para Mário o lugar da descoberta da tradição, mas do novo e do mistério trazido pelos moços. Seduzido pelo prazer sempre renovado do "descobrimento", como afirma na última carta a Rodrigo Mello Franco, o escritor encarna os princípios do modernismo, na efusiva busca de renovação estética. Traduzida pelo convívio com pessoas de geração mais nova e corporificada no gesto vital, a renovação estética embeleza e torna a vida mais "alta e agradável".

Por outro lado, a necessidade de preservação da memória e da tradição - iniciada em 1924 e oficializada em 1936, com a criação do SPHAN - tem a chancela de Mário, que redige o anteprojeto do Patrimônio, e de Rodrigo, seu diretor. Como funcionário desse órgão, Mário entrega, em 1945, o longo ensaio sobre a vida e a obra do artista colonial paulista, Padre Jesuíno

20. ANDRADE, 1990, p. 163. 
do Monte Carmelo, referência constante nas cartas a Rodrigo e o último assunto que fecha a correspondência. Exerce ainda o papel de inventariante dos bens culturais de São Paulo, descobrindo ruínas e fotografando tudo. $\mathrm{O}$ desenho cultural do país estava sendo devidamente traçado. A lição de Minas permitiu, portanto, a descoberta da convivência dos valores da tradição com os da vanguarda, do velho com o novo.

A relação epistolar com Rodrigo permite dar continuidade ao vínculo com a tradição $\mathrm{e}$, ao mesmo tempo, reforça a sua relação sempre conflituosa com o serviço público. As cartas ao então diretor do SPHAN revelam a preocupação excessiva do funcionário em prestar serviços -os relatórios são religiosamente enviados e a monografia sobre Padre Jesuíno tem data estipulada de entrega. Persistem, assim, as inquietações de ordem moral. O preço que o intelectual paga para servir ao Estado é muito alto: "Estou definitivamente chateado com as minhas perseguições morais a respeito do trabalho que faço e o tempo que dedico ao SPHAN. Você não tem nada com isso e é inútil argumentar, o caso é meu. Então escrevi em letras de ouro e sangue na consciência: se não terminar meu Jesuíno a 31 de dezembro deste ano, me demito do SPHAN." 21

A renovação estética buscada pelo último Mário se metaforiza, portanto, no seu gesto de Drácula, o grande plagiador. Essa acusação vem ao encontro a outra acusação, datada de 1937, quando Raimundo Morais declara ser Macunaíma cópia das lendas colhidas por K. Grünberg. A prática do plágio e do roubo de textos reúne a proposta estética de Mário à proposta existencial: alimenta-se, no presente, do convívio com a geração mais nova; vale-se, no passado, da apropriação de textos pertencentes ao imaginário popular e à tradição. Os limites da propriedade autoral se enfraquecem e o contato vampiresco entre os textos se expande na troca de experiências entre as gerações. Mário, mais do que ninguém, deveria se alegrar com a imagem de

21. ANDRADE, Cartas de trabalho, p. 183.
Drácula que lhe é atribuida.

A atitude vampiresca e paternal de Mário é definida por Bandeira como o seu "desejo de ser todo", expressão a que o escritor se refere em carta a Rodrigo. Entregar-se com paixão a tudo o que faz impede o gesto da escolha e acentua a doação de si sem limites ou barreiras.

Por essas razões, o Congresso será para Mário o coroamento da carreira e da sua vida. Representou não só a exposição do escritor como figura pública e atuante, como a do intelectual que responde pela cultura do país e que se sacrifica por ela. "Teve um instante, foi quando qualquer falador falou uma besteira, teve esse instante em que explodiu dentro da minha consciência a noção que aquele Congresso era o coroamento da 'minha' carreira, da minha vida ... Fiquei até com vergonha da imodéstia. Mas depois aceitei a idéia com toda a modéstia. Você não acha que sou eu, com toda essa assustadora sem-vergonhice vital, quem tem razão? Ou, melhor que razão, quem vive 'mais'?"22

Curiosamente, o escritor havia desistido de fazer do Café um romance e com ele alcançar o coroamento da carreira, pela realização da obra-prima. Tal idéia contrariava a concepção de sua obra como fragmentada e desigual e, por isso, impossível de ser representada por um texto que a totalizasse. O Congresso, contudo, cumpre essa função. $O$ coroamento da carreira e da vida se justifica pelo lado espetáculo da figura do escritor, sua "indiscrição social" e sua "sem-vergonhice vital", traços relevantes para realçar o hedonismo que norteia a entrega apaixonada à vida.

Por ter conseguido levar a discussão da literatura para o espaço público, o Congresso propicia a exteriorização de posições literárias e politicas e a saída do intelectual de seu gabinete de trabalho. Não teriam sido essas as inquietações que perseguiram Mário durante toda a vida? Indagado sobre o Congresso, o escritor iria responder: "Politicamente, magnífico; literariamen-

22. ANDRADE, Cartas de trabalho, p. 187. 
te ... acho que se abusou um pouco da arte de prolongar as idéias." 23

Na última carta de Mário a Drummond — datada de 11 de fevereiro de 1945, um dia depois da carta a Rodrigo --, a opinião do escritor sobre o Congresso muda de tom. O seu retrato vai sendo composto em nuances, ora dependendo da situação em que o escritor se encontra, ora dependendo do destinatário. A sua atitude atual é a de recolher-se em torno de seus valores individuais, desgostoso que está com os resultados do Congresso. Após uma fase de intensa doação e envolvimento com questões que "desmoralizam" sua condição de intelectual, Mário volta ao ponto de partida e repete, em outros termos, o sentimento manifestado em carta a Henriqueta, de 1941, quando se instala novamente em São Paulo.

Se, antes, a casa da rua Lopes Chaves o defendia e o "moralizava", encontra hoje, na metáfora parnasiana da "torre-de-marfim", seu escudo e fortaleza contra o apelo da vida pública.

Pela primeira vez se impôs a mim o meu, nosso destino de artistas: a Torre de Márfim. Eu sou um torre-de-marfim e só posso e devo ser legitimamente um torre-demarfim. (...) o intelectual, o artista, pela sua natureza, pela sua definição mesma de não-conformista não pode perder a sua profissão, se duplicando na profissão de político. Ele pensa, meu Deus! e a sua verdade é irrecusável pra ele. Qualquer concessão interessada pra ele, prá sua posição política, o desmoraliza, e qualquer combinação, qualquer concessão o infama. É da sua torre-de-marfim que ele deve combater, jogar desde o guspe atć o raiu di Jú piter incendiando cidades. Mas da sua torre. ${ }^{24}$

Retomando o etemo conflito vivido pelo escritor entre as contradições de sua atuação como

23. ANDRADE, Cartas de trabalho, p. 244.

24. Ibidem. 1982, p. 243. intelectual, o emprego da metáfora acentua a defesa dos valores universais do homem e da "verdade" particular do intelectual. Imune ao fascínio da política que "desmoraliza" e rompe com a integridade do artista, a torre-de-marfim permite o isolamento, sem que seja excluída a participação social. Há apenas uma diferença: tudo deverá ser feito da sua torre, sem sujar as mãos e sem envolvimento pessoal. Tornar-se, finalmente, invisível.

\section{REFERÊNCIAS BIBLIOGRÁFICAS}

1. ANDRADE, Mário de. Cândido Portinari. Revista do Patrimônio Histórico $e$ Geográfico, Rio de Janeiro, n. 20, p. 64 - 93, 1984.

2. ___. Cartas a um jovem escritor; de Mário de Andrade a Fernando Sabino. Rio de Janeiro: Record, 1981.

3. ____ Cartas de trabalho. Brasilia: MECSPHAN, 1981.

4. - A lição do amigo; cartas de Mário de Andrade a Carlos Drummond de Andrade. Rio de Janeiro: José Olympio, 1982.

5. . Querida Henriqueta. Rio de Janeiro: José Olympio, 1990.

6. BARTHES, Roland. Sade, Fourier, Loyola. Paris: Seuil, 1971.

7. BEAUJOUIR, Michel. Mirois d'encre; réthorique de l'auto portrait. Paris: Seuil, 1980.

\section{RÉSUMÉ}

Cet essai a pour but l'analyse de la position de Mario de Andrade en tant qu'intellectuel, écrivain et homme publique, aussi bien que la construction de son auto-portrait à travers l'échange épistolaire entre lui et quelques uns des écrivains de Minas Gerais. 